\title{
First confirmed record of a leucistic Antarctic fur seal pup born outside the Scotia Arc Islands
}

\author{
Wege, M. ${ }^{1 *}$, Postma, M., Tosh, C.A. ${ }^{1}$, de Bruyn, P.J.N. \& Bester, M.N. \\ ${ }^{1}$ Mammal Research Institute, Department of Zoology \& Entomology, University of Pretoria, Private Bag X20, Hatfield, \\ 0028, South Africa \\ * Corresponding author email: mwege@zoology.up.ac.za \\ Corresponding author telephone: +27784069278
}

\begin{abstract}
:
A leucistic Antarctic fur seal (Arctocephalus gazella) pup was born on subantarctic Marion Island during the austral summer of 2010/2011. This is the first confirmed record of a leucistic fur seal pup born outside the Scotia Arc islands. Additionally, we report on a leucistic adult female Antarctic fur seal producing typical black pups for five non-consecutive summers on Marion Island. The birth of a leucistic pup, together with the multiple black pups produced by the leucistic female, suggests that the recessive genes responsible for leucism are now entrenched within the Marion Island population.
\end{abstract}

Key Words: Leucism, Antarctic fur seal, Arctocephalus gazella, Marion Island 
Leucism, and other forms of hypo-pigmentation, are relatively common in Antarctic fur seal (Arctocephalus gazella) populations within the Scotia Arc and thought to be due to the founder effect (Bonner 1968, Acevedo et al. 2009) arising from remnant populations (<100 individuals) breeding at South Georgia at the time of population recovery (Wynen et al. 2000). At least one leucistic individual was known to survive there to adulthood (Bonner 1968). Outside of the Scotia Arc leucistic Antarctic fur seals have only been observed on Bouvetøya (Hofmeyr et al. 2005a, b) and Marion Island (de Bruyn et al. 2007). None of these individuals reported outside the Scotia Arc were pups.

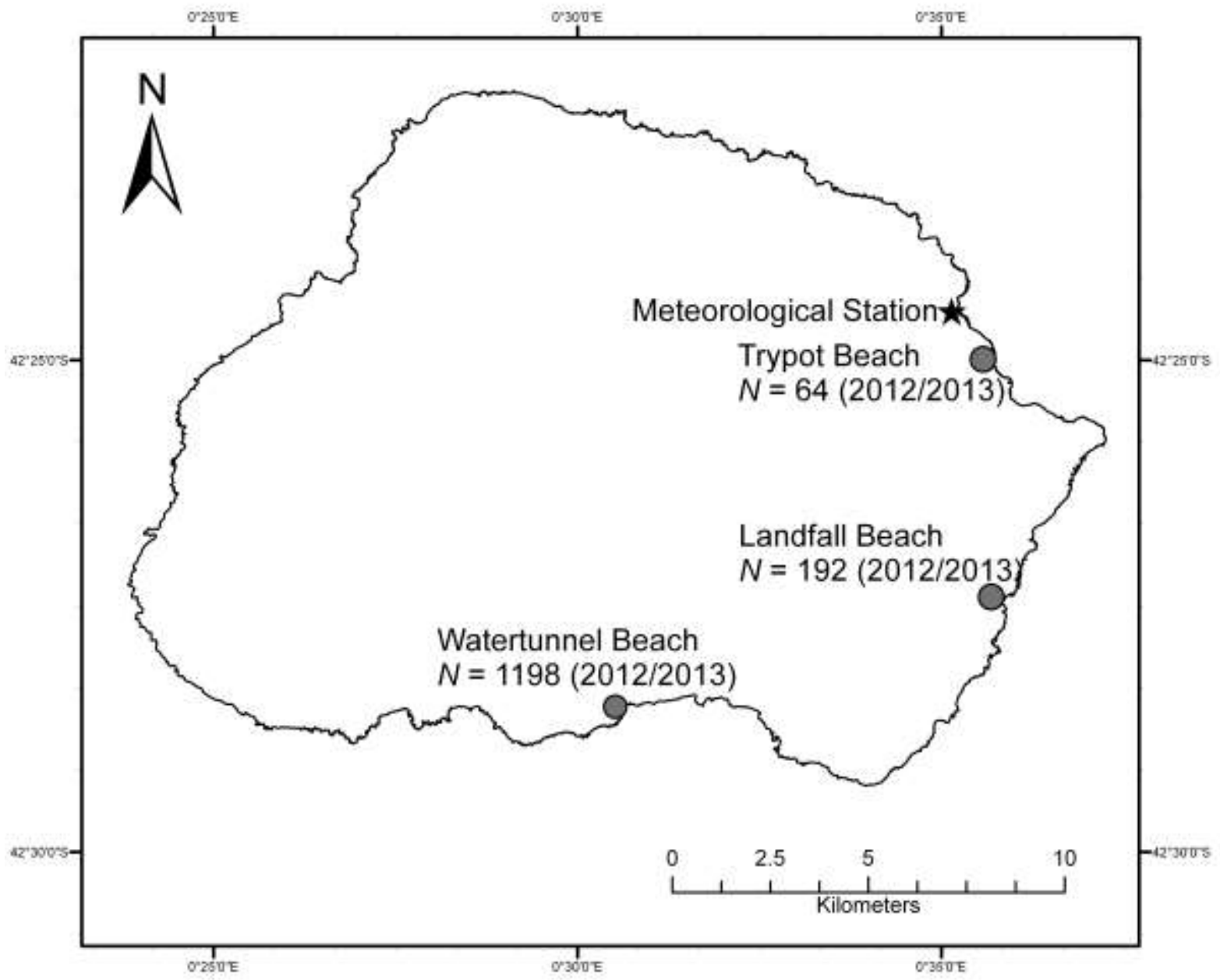

Figure 1 Primary Antarctic fur seal (Arctocephalus gazella) breeding colonies at Marion Island $\left(\mathbf{4 6}^{\circ} \mathbf{5 2} \mathbf{S}^{\prime} \mathbf{S}, \mathbf{3 7}^{\circ} \mathrm{51}^{\prime} \mathrm{E}\right)$ with the estimated pup production for 2012/13.

A leucistic Antarctic fur seal pup was born at Landfall Beach, Marion Island (MI) (46 $56^{\prime} 40.21^{\prime \prime} \mathrm{S}$ $37^{\circ} 52^{\prime}$ 26.03' E; Fig. 1 and 2) during the austral summer of 2010/2011. The pup's mother (relationship confirmed at multiple suckling sightings) was a normally coloured individual, being uniformly grey in colour 


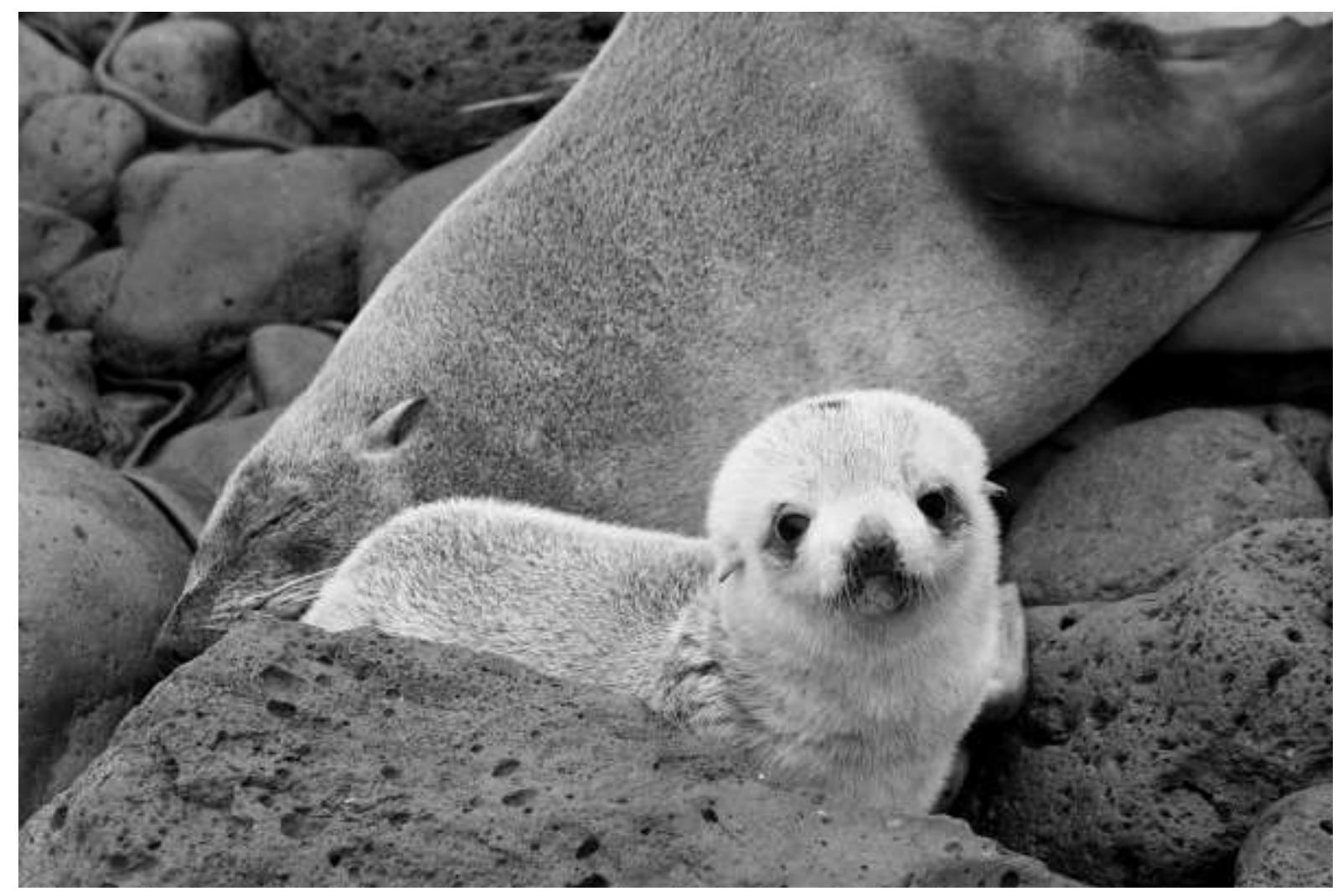

Figure 2 Leucistic Antarctic fur seal pup (Arctocephalus gazella) born at Marion Island (16 December 2010). Photo credit: C.

Oosthuizen

(Bonner 1968). The pup weaned successfully in April 2011, but was subsequently never resighted despite extensive field researcher presence through intensive multi-species seal research at MI (de Bruyn et al. 2007, Bester et al. 2011). A leucistic adult female was recorded during the breeding seasons of 2006/2007, 2007/2008, 2009/2010, 2010/2011 and 2011/2012 at Landfall Beach (Fig. 1) with a typically coloured black pup (Fig. 3).

Leucistic individuals of any species can be identified by a total or partial lack of pigmentation in the pelage but still have normally coloured eyes and body extremities (Fertl \& Rosel 2002, Rook et al. 1998) whereas albino individuals have abnormally coloured eyes. It is unclear whether the adult female was completely or partially leucistic, but Summers (2009) dismisses the distinction between "partial" and "total" hypo-pigmentation as obsolete. Although some authors are still divided on the use of this terminology (references within Summers 2009), the female in question definitely displayed a form of hypo-pigmentation and for consistency's sake we will refer to her as leucistic.

Whilst the exact genes responsible for leucism have not been identified (Fertl \& Rosel 2002; Summers 2009; Abreu et al. 2013), the mutation is known to be recessive (Hoekstra 2006). The relative genetic 

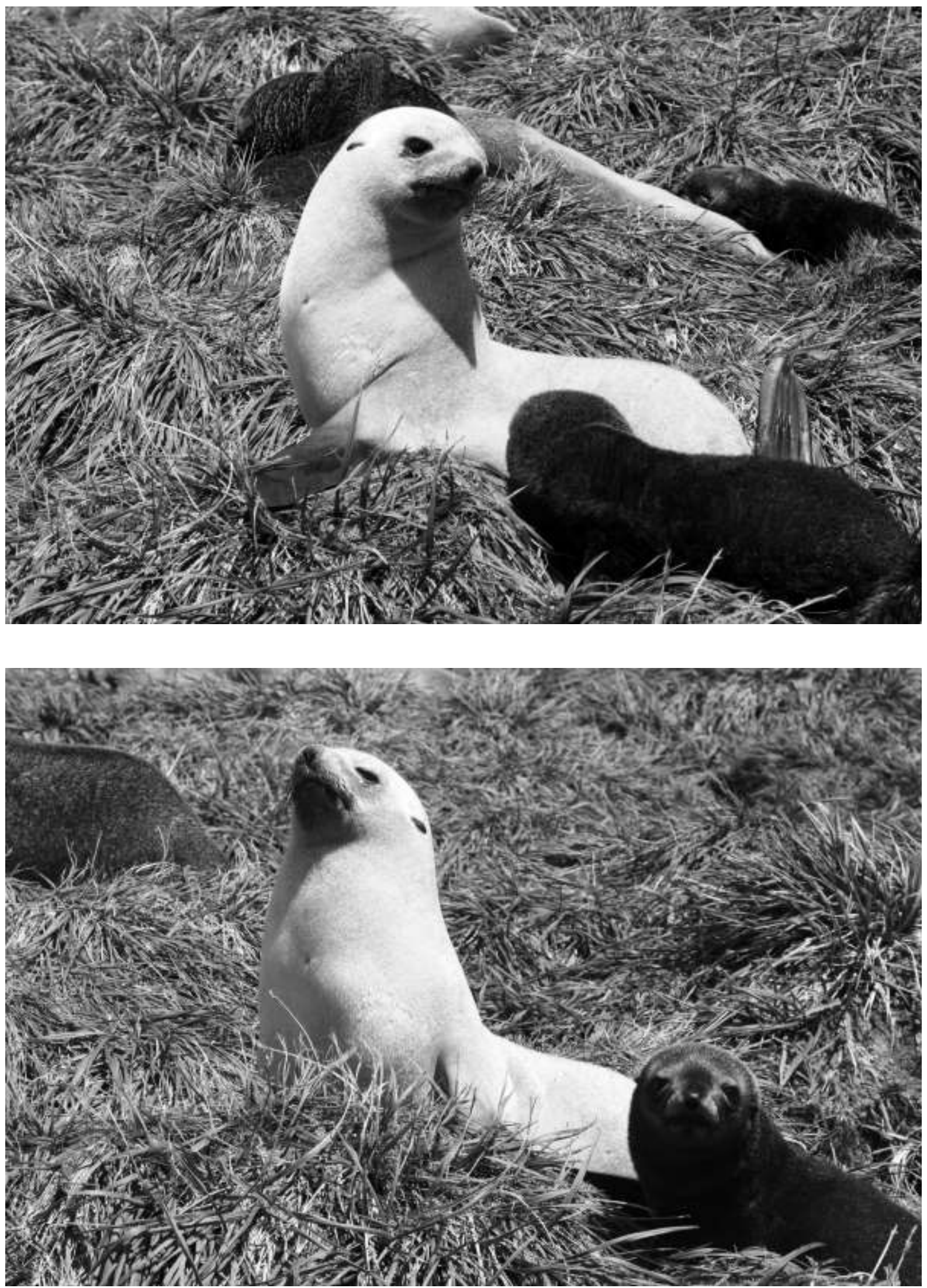

Figure 3 Leucistic Antarctic fur seal female (Arctocephalus gazella) with her normally coloured pup at Landfall Beach in January 2010. Photo credit: M. Wege 
differentiation between populations is related to the relationship between colonisation and migration between populations, as well as genetic mutations (Wade \& McCauley 1988). The expression of a relatively rare genetic trait at MI, i.e. leucism, is an indication of the continued emigration of Antarctic fur seals from the Scotia Arc and their subsequent colonisation at MI. This poses some important questions regarding how much of MI's current exponential population growth (Hofmeyr et al. 2006) can be attributed to internal population growth versus how much is the result of immigration from other potentially saturated populations in the Scotia Arc and Bouvetøya populations (Boyd 1993, Hofmeyr et al. 2005b). Recently, Forcada \& Hoffman (2014) identified a decline in the Antarctic fur seal population at South Georgia, one of the islands within the Scotia Arc. Although they attributed the decline to climatic shifts, factors such as emigration cannot be ruled out entirely.

Fur seal populations at Marion Island are closely monitored as part of the Marion Island Pinniped Monitoring Programme (Bester et al. 2011). The leucistic individuals described here were all observed at Landfall Beach, MI (Fig. 1). A leucistic sub-adult male Antarctic fur seal was also recorded at Watertunnel and Trypot beaches (Fig. 1) in 2007 (de Bruyn et al. 2007) but was not recorded again. Regular visits to the main fur seal rookeries on MI suggest that this is the first leucistic pup born on Marion Island (this study) after the recolonization of the species here (Kerley 1983).

The repeated sightings of the leucistic female breeding at MI over several summers indicate that the recessive genes linked to leucism are being introduced into the gene pool of the population. The eventual expression of the trait in a pup indicates that both parents were carriers of this recessive gene. Although Antarctic fur seals have low levels in population genetic structure, the MI population shares common alleles with seals from South Georgia/ Bouvetøya (Wynen et al. 2000). This is thought to be the result ofimmigration from these proposed source populations (Wynen et al. 2000). Whilst the natal site and reproductive history of the leucistic pup's mother is unknown it is likely that she shows breeding site fidelity, as is evident for this species (Lunn \& Boyd 1991), to MI and may breed there again. Given that the globally rare leucistic gene was expressed in a pup born on MI and the continued breeding of an aberrantly coloured adult female at this location, suggest this recessive gene is now entrenched into the genetic structure of the MI fur seal population. Further genetic studies are required to describe the change in genetic structuring of this population, given its continued growth, in relation to other fur seal populations over time. 


\section{Acknowledgements:}

The Department of Environmental Affairs provided logistic support within the South African National Antarctic Programme. The Department of Science and Technology, through the National Research Foundation (South Africa), provided financial support. Thank you to Chris Oosthuizen for the photos of the leucistic pup and Derek van der Merwe, Hugh Purdon, Jean Purdon and Tristan Scott for other observations of the leucistic female.

\section{References:}

Abreu MSL, Machado R, Barbieri F, Freitas NS, Oliveira LR (2013) Anomalous colour in Neotropical mammals: a review with new records for Didelphis sp. (Didelphidae, Didelphimorphia) and Arctocephalus australis (Otariidae, Carnivora). Braz J Biol 73:185-194

Acevedo J, Torres D, Aguayo-Lobo A (2009) Rare piebald and partially leucistic Antarctic fur seals, Arctocephalus gazella, at Cape Shirreff, Livingston Island, Antarctica. Polar Biol 32: 41-45

Bester MN, De Bruyn PJN, Oosthuizen WC, Tosh CA, McIntyre T, Reisinger RR, Postma M, Van der Merwe DS, Wege M (2011) The Marine Mammal Programme at the Prince Edward Islands: 38 years of research. Afr J Mar Sci 33:511-521

Bonner WN (1968) The fur seal of South Georgia. Sci Rep Br Antarct Surv 56:1-88

Boyd IL (1993) Pup production and distribution of breeding Antarctic fur seals (Arctocephalus gazella) at South Georgia. Ant Sci 5: 17-24

De Bruyn PJN, Pistorius PA, Tosh CA, Bester MN (2007) Leucistic Antarctic fur seal at Marion Island. Polar Biol 30:1355-1358

Fertl D, Rosel PE (2002) Albinism. In: Perrin WF, Würsig B, Thewissen JGM (eds) Encyclopedia of marine mammals. Academic, San Diego, pp 16-18

Forcada J \& Hoffman JI (2014) Climate change selects for heterozygosity in a declining fur seal population. Nature 511: 462-465

Hoekstra HE (2006) Genetics, development and evolution of adaptive pigmentation in vertebrates. Heredity 97:222-234 
Hofmeyr GJG, Bester MN, Kirkman SP (2005a) Leucistic Antarctic fur seals at Bouvetøya. Polar Biol 29:77-79

Hofmeyr GJG, Kraft BA, Kirkman SP, Bester MN, Lydersen C, Kovacs KM (2005b) Population changes of Antarctic fur seals at Nyrøysa, Bouvetøya. Polar Biol 28: 725-731Hofmeyr GJG, Bester MN, Makhado AB, Pistorius PA (2006) Population changes in Subantarctic and Antarctic fur seals at Marion Island. S Afr J Wildl Res 36:55-68

Kerley GIH (1983) Relative population sizes and trends, and hybridization of fur seals Arctocephalus tropicalis and A. gazella at the Prince Edward Islands. S Afr J Zool 18:388-392

Lunn NJ, Boyd IL (1991) Pupping-site fidelity of Antarctic fur seals at Bird Island, South Georgia. J. Mamm 72:202-206

Rook A, Wilkinson DS, Ebling FJB, Champion RH, Burton JL (eds) (1998) Textbook of dermatology, 4th edn. Blackwell, Oxford, p4144

Summers CG (2009). Albinism: classification, clinical characteristics, and recent findings. Opt Vis Sci 86:659662

Wade MJ, McCauley DE (1988) Extinction and recolonization: their effects on the genetic differentiation of local populations. Evol 42:995-1005

Wynen LP, Goldsworthy SD, Guinet C, Bester MN, Boyd IL, Gjertz I, Hofmeyr GJG, White RWG, Slade R (2000) Postsealing genetic variation and population structure of two species of fur seal (Arctocephalus gazella and A.tropicalis). Mol Ecol 9:299-314 